\title{
SELENIUM IN STORAGE PROTEINS OF WHEAT CULTIVATED ON SELENIUM IMPACTED SOILS OF PUNJAB, INDIA
}

\author{
S.K. JAISWAL ${ }^{\mathrm{a}}$, R. Prakash ${ }^{\mathrm{b}}$ and T.P. NAGARAJA ${ }^{\mathrm{c} *}$ \\ ${ }^{a}$ Department of Biotechnology, Thapar University, Patiala 147004. India \\ ${ }^{\mathrm{b}} \mathrm{S} c h o o l$ of Chemistry and Biochemistry, Thapar University, Patiala 147004. India \\ 'School of Energy and Environment, Thapar University, Patiala 147004. India
}

(Received: 23 February 2013; accepted: 14 July 2013)

\begin{abstract}
Wheat, an important staple cereal crop cultivated in seleniferous region of India, noted to accumulated significantly high concentrations of Se, was examined for the distribution of selenium in various protein fractions of the grains. Amongst the protein fractions, Se was dominantly (33-37\%) present in the albumin fraction in Se rich grains followed by other fractions viz., globulin (20-25\%), glutelin (20-25\%), and prolamin (17-20\%). The observations are important in context of exploring the use of this material as functional foods in formulating Se-enriched diets for Se-deficient population.
\end{abstract}

Keywords: selenium, wheat, proteins, fraction

Selenium (Se) is an essential micronutrient for humans and animals, involved as selenocysteine (SeCys) in functioning at the catalytic centre of several selenoproteins, such as glutathione peroxidases (GPx), thioredoxin reductase (TRx), and iodothyronine-deiodinases (DIs) (RAYMAN, 2002). As a constituent in different selenium containing enzymes and proteins, Se performs various functions, such as protection of body tissues against oxidative stress, immune function, reproduction, and modulation of growth and development (FAIRWEATHERTAIT et al., 2011). With the growing importance and increasing evidence of the role of Se, countries such as Finland and UK (BROADLEY et al., 2006) have been involved in agronomic biofortification of selenium during cultivation of wheat. Studies also indicate that interspecies variations play a significant role in the genetic and agronomic fortification of Se in wheat for consumer diets (BónA et al., 2008).

Se has no known physiological function in plants (Sors et al., 2005) and is metabolized via the S-assimilation pathway, which involves biosynthesis of selenoamino acids, i.e., SeCys and selenomethionine (SeMet), and other seleno-compounds, such as Se-methylselenocysteine (MeSeCys), g-glutamyl-Se-methylselenocysteine (GGMeSeCys), and selenocystothioneine, which, however, are non-specifically incorporated into proteins in place of cysteine and methionine, respectively (AURELI et al., 2013).

Because of the narrow range existing between Se deficiency and toxicity, and since plants can accumulate huge amounts of Se, this metalloid can be toxic to humans and livestock. Human toxicity from dietary exposure to Se is rare and it was only reported in seleniferous areas, e.g., the Enshi District (China) and Nawanshahr Region (India), where the population heavily relies upon local produce for their food (FORDYCE et al., 2000; HIRA et al., 2004).

\footnotetext{
* To whom correspondence should be addressed. Phone: +91-175-2393318; fax:+91-175-2364468; e-mail: ntejoprakash@thapar.edu
} 
Among the few locations in the world, seleniferous areas have been identified in certain states in India (Dhillon \& Dhillon, 2003). The largest one (>1000 ha) is the seleniferous belt of the District Nawanshahr $\left(31^{\circ} 13^{\prime} \mathrm{N}, 76^{\circ} 21^{\prime}\right.$ E, Punjab, India) with significantly high Se concentrations being reported in locally grown crops (SHARma et al., 2009). The quantification and speciation studies carried out by our group indicated that wheat, cultivated in this region, is able to accumulate Se at concentrations up to $146 \mu \mathrm{g} \mathrm{g}^{-1}$ in vegetative tissues and $185 \mu \mathrm{g} \mathrm{g}^{-1}$ in grain, with selenomethionine (SeMet) constituting dominant fraction $(>75 \%)$ followed by selenite and selenocystine (Aureli et al., 2013).

Based on the observations on significantly high uptake of Se by wheat cultivated in the region, we attempted to study the distribution of Se amongst the dominant storage proteins, like albumins, glutelins, globulins, and prolamins.

\section{Materials and methods}

\subsection{Chemicals}

The analytical chemicals such as hexane (solvent grade), sodium chloride $(\mathrm{NaCl})$, sodium hydroxide $(\mathrm{NaOH})$, ammonium sulphate $\left(\left(\mathrm{NH}_{4}\right)_{2} \mathrm{SO}_{4}\right)$, hydroxylamine hydrochloride $\left(\mathrm{NH}_{2} \mathrm{OH} . \mathrm{HCl}\right)$, nitric acid $\left(\mathrm{HNO}_{3}\right)$, perchloric acid $\left(\mathrm{HClO}_{4}\right)$, and hydrochloric acid $(\mathrm{HCl})$ were procured from SD Fine Chemicals, Mumbai, India. Formic acid, absolute ethanol, and cyclohexane were obtained from Lobachem, Mumbai, India. $\mathrm{Na}_{2}$ EDTA and 2,3-diaminonaphthalene (DAN) were purchased from Himedia, Mumbai, India. All chemicals used in the experiments were of analytical grade and used without further purification except DAN.

\subsection{Samples}

Samples of wheat (Triticum aestivum, cv. PBW343) were collected at sites near the villages of Jainpur (high Se impact) and Barwa (moderate Se impact) geographically located at $31^{\circ} 13^{\prime} \mathrm{N}, 76^{\circ} 21^{\prime} \mathrm{E}$, in the Nawanshahr-Hoshiarpur region of Punjab (India). The impact of Se in soils and crops was considered based on the report by Dhillon and Dhillon (2003). Samples from Patiala district $\left(30^{\circ} 34^{\prime} \mathrm{N}, 76^{\circ} 38^{\prime}\right.$ E), which is located about 75 miles away from the seleniferous region, were collected to represent non-seleniferous region. Collected samples were manually cleaned, washed with water, and air-dried for 2 days. Sample handling was carried out in a clean room under a laminar flow chamber. Whole wheat grains were grounded into fine powder using Warner electric grinder impregnated with stainless steel blade. Precautions were taken during sample preparation by cleaning of the grinding apparatus with ethanol after homogenization of every sample. Each wholemeal wheat flour sample was passed through a $0.5 \mathrm{~mm}$ sieve to make homogenous fine powder. About $50 \mathrm{~g}$ of different wheat flour samples were transferred to $250 \mathrm{ml}$ conical flask containing $100 \mathrm{ml}$ hexane and defatted samples were dried under laminar hood at room temperature for $24 \mathrm{~h}$.

\subsection{Preparation of DAN solution}

Diaminonaphthalene (DAN) solution was prepared by dissolving $0.1 \mathrm{~g}$ of DAN into $100 \mathrm{ml}$ of $0.1 \mathrm{~N} \mathrm{HCl}$ containing $0.5 \mathrm{~g}$ of $\mathrm{NH}_{4} \mathrm{OH} . \mathrm{HCl}$ in an amber bottle and kept at $50{ }^{\circ} \mathrm{C}$ for $30 \mathrm{~min}$ in water bath. On cooling, solution was extracted twice with $20 \mathrm{ml}$ cyclohexane to remove impurities. The aqueous layer was then separated and stored at $4{ }^{\circ} \mathrm{C}$ in a brown bottle. 


\subsection{Protein fractionation}

Different protein fractions were extracted from defatted wheat flour on the basis of their solubility at $25{ }^{\circ} \mathrm{C}$ with distilled water (for albumin), $5 \% \mathrm{NaCl}$ (for globulin), $0.1 \mathrm{M} \mathrm{NaOH}$ (for glutelin), and 70\% ethanol (for prolamin) following the procedure given by Ju and coworkers (2001).

\subsection{Determination of selenium}

Selenium was determined in defatted wheat flour, starch residue (residue left after extraction), and all dry protein fractions using fluorescence spectrometric method (LEVESQUE \& VENDETTE, 1971). This method involved digestion with $\mathrm{HNO}_{3}$ and $\mathrm{HClO}_{4}$, reduction of selenium from $\mathrm{Se}^{+6}$ to $\mathrm{Se}^{+4}$ with $\mathrm{HCl}$, complexing of $\mathrm{Se}^{+4}$ with DAN to form piazselenol and extraction of the piazselenol in cyclohexane. The cyclohexane layer was washed with $5 \mathrm{ml} 0.1 \mathrm{~N} \mathrm{HCl}$. The emission spectrum of piazselenol complex formed during the reaction was measured using fluorescence spectrometer (Perkin Elmer LS-45, USA) at excitation and emission wavelength of 360 and $520 \mathrm{~nm}$, respectively. Se quantification in each sample was carried out by relative method using emission spectrum of NIST certified Se-ICP standard solution (SRM-1349). The results are expressed as mean \pm standard deviation.

\section{Results and discussion}

The storage protein fractions of cereals such as wheat contain four different species of proteins, that is albumins, glutelins, globulins, and prolamins, and are generally called as 'Osborne' fractions. Seed storage proteins are generally accumulated in significant quantities in developing seed and generally constitute the major source of nitrogen during germination and early stages of seedling growth (Higgins, 1984). In cereals, the albumins and globulins are concentrated in the seed coats, the aleurone cells, and the germ, with somewhat lower concentrations in the mealy endosperm (SRAMKOVA et al., 2009). The albumin and globulin fraction cover about 25\% of the total grain proteins (BELDEROK et al., 2000). Most of the physiologically active proteins are found in the albumin and globulin groups. Glutelins, along with gliadins, cover about $75 \%$ of the total protein content. They are mainly located in the mealy endosperm (SRAmKova et al., 2009).

Proteins were extracted and separated from the Se-rich wheat as described earlier and the overall distribution of Se found in different protein and non-protein residual fractions is presented in Table 1.

The majority of Se was found in protein fractions when compared to the non-protein residue. There was significant difference in the selenium levels in fractions separated from the wheat of the three different sites with varying environmental selenium levels, indicating the variations in selenium accumulation pattern. Although, glutelins comprised the dominant group of proteins $(65-70 \%)$ in wheat grain, the selenium content with reference to protein fraction was more prominent in albumins, which comprised $38-40 \%$ of the protein fraction followed by glutelins, globulins (25-30\%), and prolamins (25-30\%) (Fig. 1).

Present observations also reveal that Se was mostly stored $(>77 \%)$ in wheat protein with a small portion being retained in the non-protein fraction, such as carbohydrate, lipid, and fibre complexes of wheat. 
Table 1. Se content in whole grain, protein and non-proteinous residues of wheat collected from regions varying in environmental selenium levels.

\begin{tabular}{|c|c|c|c|c|c|c|}
\hline \multirow[t]{3}{*}{ Wheat source (field) } & \multicolumn{6}{|c|}{ Se content $\left(\mu \mathrm{g} \mathrm{g}^{-1}\right)$} \\
\hline & \multirow[t]{2}{*}{ Wheat flour } & \multirow{2}{*}{$\begin{array}{l}\text { Non-protein } \\
\text { residue after } \\
\text { extraction }\end{array}$} & \multicolumn{4}{|c|}{ Protein fractions } \\
\hline & & & Albumin & Globulin & Glutelin & Prolamin \\
\hline Highly seleniferous & $46.29 \pm 2.20$ & $13.36 \pm 0.21$ & $233.9 \pm 5.80$ & $149.5 \pm 4.90$ & $197.9 \pm 3.10$ & $122.6 \pm 2.00$ \\
\hline Moderately seleniferous & $12.20 \pm 0.12$ & $3.43 \pm 0.10$ & $94.05 \pm 3.30$ & $50.22 \pm 1.40$ & $49.04 \pm 4.10$ & $56.23 \pm 1.40$ \\
\hline Non-seleniferous & $1.86 \pm 0.20$ & $\mathrm{BDL}$ & $13.67 \pm 0.70$ & $12.27 \pm 0.40$ & $15.68 \pm 1.50$ & $10.21 \pm 1.60$ \\
\hline
\end{tabular}

The data is mean of three determinations \pm standard deviation. BDL represents below detection limit.

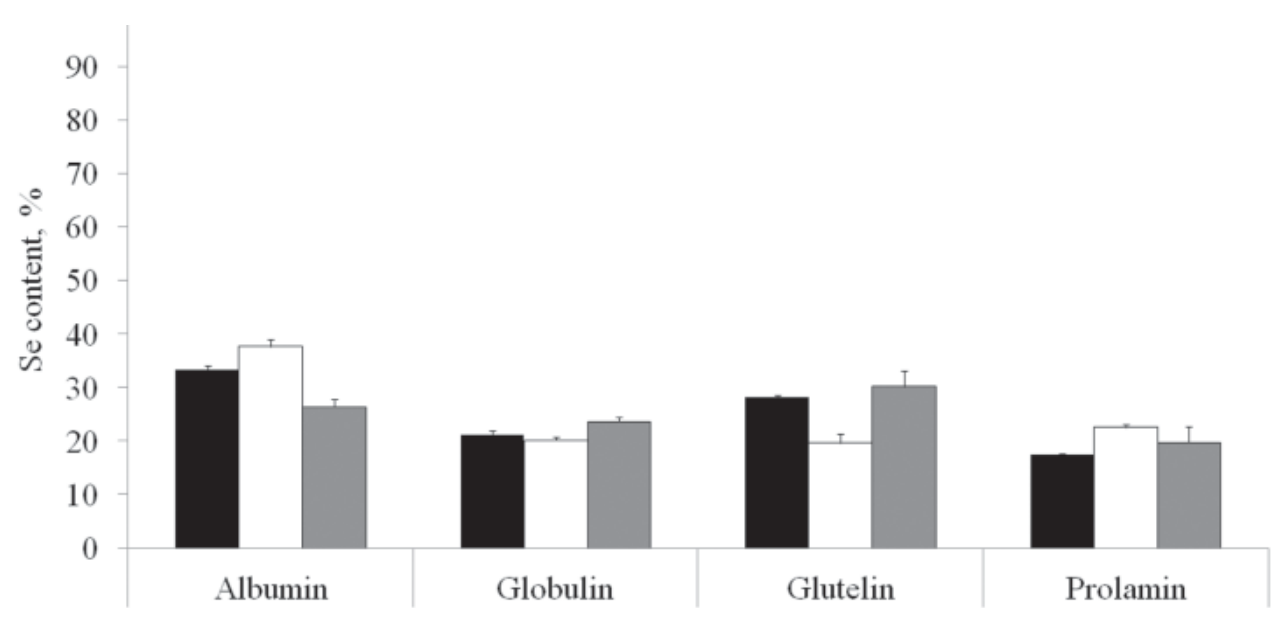

Fig. 1. Selenium content in wheat collected from three different fields with varying impact of selenium घ: Wheat from Se-rich fields; $\square$ : Wheat from moderately Se-impacted fields; and $\square$ : Wheat from non-seleniferous fields. The data $(n=3)$ is depicted in terms of percentage (mean $\pm \mathrm{SD})$

Our recent observations indicated that Se in wheat is distributed in approximately $1: 2$ ratio between the water-soluble fraction containing small molecular weight metabolites and the water insoluble fractions (AureLi et al., 2013). However, the speciation in water insoluble fractions has been a very difficult task (BIANGA et al., 2013). Fractionation scheme, carried out by FANG and co-workers (2010), showed that the largest Se content was found in the glutelin fraction of rice grains, which is observably different from the present study on wheat. Recent report by BIANGA and co-workers (2013) demonstrated an approach to describe family of storage proteins belonging to glutenin group that notably accumulate selenium. The study also showed evidence for the substitution of sulphur by selenium in cysteine. The $\mathrm{Se}$ concentration in different protein fractions seems to represent abundance of methionine (Met) and cysteine (Cys) in each fraction, since selenocysteine (SeCys) and selenomethionine (SeMet) are non-specifically incorporated into proteins in place of Cys and Met, respectively. Protein-bound SeMet is the predominant Se type in wheat grain and typically accounts for $70-85 \%$ of the Se present (StADlOBER et al., 2001). Our previous studies showed organoselenium compounds other than SeMet accounting up to $18-22 \%$ of the total 
chromatographed Se (CuBADDA et al., 2010). In addition, observations on bioaccessibility of Se-rich wheat grains showed SeMet having high bioavailability $(>90 \%)$ during in vitro gastric and gastro-intestinal digestion as well as simulated human intestinal microbial environment (DiAz-BONE et al., 2010), indicating that high Se in wheat grain, therefore, has high bioavailability. In wheat grain, Se is mostly protein-bound and more evenly distributed throughout the kernel than other minerals, thus little Se is removed in the milling process and the concentration in flour is usually $80-90 \%$ of that in grain (Lyons et al., 2005; CuBADDA et al., 2009).

Wheat produced in Western Europe contains only $1 / 10^{\text {th }}$ of the selenium that is present in wheat grown in North America (COMBS \& GRAY, 1998). For example, the mean value of Se in wheat sampled in UK is $27 \mu \mathrm{g} \mathrm{Se} \mathrm{kg}{ }^{-1}$ compared to $370 \mu \mathrm{g} \mathrm{Se} \mathrm{kg}^{-1}$ in the USA (WoLnIK et al., 1983; ADAMs et al., 2002). To counter the decreased intake of selenium in diet, one of the important strategies followed was to fertilize crops with selenium, as was practiced in Finland and in the UK (BROAdLEY et al., 2006) to a certain extent. Another important paradigm that has been emerging in the recent past is the use of cereal grains cultivated in Se-rich soils that are naturally enriched with selenium and containing unique selenium compounds, as nutritional or supra-nutritional supplements (KoKARNIG et al., 2011).

Cereal grains provide a significant portion of protein for the nutrition of humans and livestock. In addition to nutritional importance, cereal seed proteins also influence the utilization of the grain in food processing, especially in case of wheat, which is largely consumed after processing. Storage proteins account to about 50\% of the total protein in mature cereal grains and have important impact on their nutritional quality and on their functional properties. In addition to their nutritional importance, wheat proteins also influence the utilization of the grain in food processing (SHEWRY \& HALFORD, 2002). Therefore, the use of Se rich wheat for human supplementation requires a better understanding of the uptake and accumulation of $\mathrm{Se}$ in various protein fractions.

\section{Conclusions}

Keeping this in view, the present study describes the distribution profile of selenium in storage proteins, that is albumins, globulins, prolamins, and glutelins, in wheat collected from the seleniferous fields in comparison to those cultivated in non-seleniferous fields. The primary goal of the on-going studies on cereals cultivated in the said region is to explore the opportunities of using locally grown grains for fortification of low-Se grain batches or production of naturally enriched products as Se supplements for human and animal nutrition. Understanding the selenium fractionation in the storage proteins as carried out in this study opens an insight on biological mechanisms that determine their trafficking and deposition in the grain and lead to future attempts to improve the end use of these dietary sources of selenium toward nutritional supplementation and food fortification.

The authors acknowledge the funding provided by BRNS, Government of India for the present work carried out on selenium quantification and speciation. 


\section{References}

Adams, M.L., Lombi, E., Zhao, F.J. \& McGrath, S.P. (2002): Evidence of low selenium concentrations in UK bread making wheat grain. J. Sci. Food Agric., 82, 1160-1165.

Aureli, F., Ouerdane, L., Bierla, K., Szpunar, J., Tejo Prakash, N. \& Cubadda, F. (2013): Identification of selenosugars and other low-molecular weight selenium metabolites in high selenium cereal crops. Metallomics, 4, 968-978.

Belderok, B., Mesdag, H. \& Donner, D.A. (2000): Bread-making quality of wheat: A century of breeding in Europe. Kluwer Academic Press, The Netherlands. 419 pages.

Bianga, J., Govasmark, E. \& Szpunar, J. (2013): Characterization of selenium incorporation into wheat proteins by two-dimensional gel electrophoresis-LA-ICP-MS followed by capillary HPLC-ICP-MS and ES-LTQuadrupole Orbitrap MS. Anal. Chem., 85, 2037-2043.

Bóna, L., AdÁnyi, N., Farkas, R., Szanics, E., Szabó, E., Hajós, G., Pécsváradi, A. \& Ács, E. (2008): Variations in crop nutrient accumulation: Selenium content of wheat and triticale grains. Acta Alimentaria, 38, 9-15.

Broadley, M.R., White, P.J., Bryson, R.J., Meacham, M.C., Bowen, H.C., Johnson, S.E., Hawkesford, M.J., McGrath, S.P., Zhao, F.J., Breward, N., Harriman, M. \& Tucker, M. (2006): Biofortification of UK food crops with selenium. Proc. Nutr. Soc., 65, 169-181.

Combs, G.F. \& Gray, W.P. (1998): Chemopreventive agents: Selenium. Pharmacol. Ther. 79, 179-192.

Cubadda, F., Aureli, F., Raggi, A. \& Carcea, M. (2009): Effect of milling, pasta making and cooking on minerals in durum wheat. J. Cereal Sci., 49, 92-97.

Cubadda, F., Aureli, F., Ciardullo, S., D’Amato, M., Raggi, A., Acharya, R., Reddy, A.V.R. \& Tejo Prakash, N. (2010): Changes in selenium speciation associated with increasing tissue concentration of selenium in wheat grain. J. Agric. Food Chem., 58, 2295-2301.

Dhillon, K.S. \& Dhillon, S.K. (2003): Distribution and management of seleniferous soils. Adv. Agron., 79, 119184.

Diaz-Bone, R.A., Van de Wiele, T., Cubadda, F. \& Tejo Prakash, N. (2010): Biovolatilization of selenium, tellurium and sulphur by intestinal microorganisms. II International Conference on Research Frontiers in Chalcogen Cycle Science and Technology, Delft, Netherlands, p. 19.

Fairweather-Tait, S.J., Bao, Y., Broadley, M.R., Collings, R., Ford, D., Hesketh, J.E. \& Hurst, R. (2011): Selenium in human health and disease. Antioxid. Redox Signal., 14, 1337-1383.

Fang, Y., Catron, B., Zhang, Y., Zhao, L., Caruso, J.A. \& Hu, Q. (2010): Distribution and in vitro availability of selenium in selenium-containing storage protein from selenium-enriched rice utilizing optimized extraction. J. Agric. Food Chem., 58, 9731-9738.

Fordyce, F.M., Zhang, G., Green, K. \& Liu, X. (2000): Soil, grain and water chemistry in relation to human selenium-responsive diseases in Enshi District, China. Appl. Geochem., 15, 117-132.

Higgins, T.J.V. (1984): Synthesis and regulation of major proteins in seeds. Ann. Rev. Plant Physiol., 35, 191-221.

Hira, C.K., Partal, K. \& Dhillon, K.S. (2004): Dietary selenium intake by men and women in high and low selenium areas of Punjab. Publ. Health Nutr., 7, 39-43.

Ju, Z.Y., Hettiarachchy, N.S. \& Rath, N. (2001): Extraction, denaturation and hydrophobic properties of rice flour proteins. J. Food Sci., 66, 229-232.

Kokarnig, S., Kuehnelt, D., Stiboller, M., Hartleb, U. \& Francesconi, K.A. (2011): Quantitative determination of small selenium species in human serum by HPLC/ICPMS following a protein-removal, pre-concentration procedure. Anal. Bioanal. Chem., 400, 2323-2327.

Levesque, M. \& Vendette, E.D. (1971): Selenium determination in soil and plant materials. Can. J. Soil Sci., 51, 85-93.

Lyons, G.H., Genc, Y., Stangoulis, J.C.R., Palmer, L.T. \& Graham, R.D. (2005): Selenium distribution in wheat grain and the effect of postharvest processing on wheat selenium content. Biol. Trace Elem. Res., 103, 155168.

RaYman, M.P. (2002): The argument for increasing selenium intake. Proc. Nutr. Soc., 61, 203-215.

Sharma, N., Prakash, R., Srivastava , A., Sadana, U.S., Acharya, R., Tejo Prakash, N. \& Reddy, A.V.R. (2009): Profile of selenium in soil and crops in seleniferous area of Punjab, India by neutron activation analysis. J. Radioanal. Nucl. Chem., 281, 59-42.

Shewry, P.R. \& Halford, N.G. (2002): Cereal seed storage proteins: Structures, properties and role in grain utilization. J. Exp. Bot., 53, 947-958.

Sors, T.G., Ellis, D.R. \& Salt, D.E. (2005): Selenium uptake, translocation, assimilation and metabolic fate in plants. Photosynth. Res., 86, 373-389. 
Sramkova, Z., Gregova, E. \& Sturdik, E. (2009): Chemical composition and nutritional quality of wheat grain. Acta Chim. Slov., 2, 115-138.

Stadlober, M., Sager, M. \& Irgolic, K.J. (2001): Effects of selenate supplemented fertilisation on the selenium level of cereals - Identification and quantification of selenium compounds by HPLC-ICP-MS. Food Chem. 73, $357-366$.

Wolnik, K.A., Fricke, F.L., Capar, S.G., Braude, G.L., Meyer, M.W., Satzger, R.D. \& Kuennen, R.W. (1983): Elements in major raw agricultural crops in United States. 2. Other elements in lettuce, peanuts, potatoes, soybeans, sweet corn and wheat. J. Agric. Food Chem., 31, 1244-1249. 